\title{
På tide å pensjonere tuberkulintestene?
}

I mer enn hundre år har kutane tuberkulintester vært dominerende for å påvise infeksjon med Mycobacterium tuberculosis. Nye, spesifikke analyser av blodprøver, såkalte Interferon-gamma Release Assays (IGRA), er et viktig diagnostisk fremskritt, både ved latent tuberkulose og ved mistanke om aktiv tuberkuløs sykdom. Testene krever bare én kontakt med helsevesenet, gir et ja-eller-nei-svar, har høy spesifisitet, og gjennomføring krever ikke spesialutdannet personell. Tiden er sannsynligvis moden for å plassere tuberkulintestene på museum.

\section{Dag Gundersen Storla} dags@lds.no

Seksjon for infeksjonsmedisin Lovisenberg Diakonale Sykehus Lovisenberggata 17 0440 Oslo

Gjennom flere årtier har det vært drevet forskning på mykobakterielle antigener. Hovedmålet har vært å finne en mer effektiv vaksine enn BCG (Bacillus Calmette-Guérin) mot tuberkulose. Man har særlig konsentrert seg om proteiner som Mycobacterium tuberculosis utskiller aktivt, fordi disse trolig setter i gang en immunreaksjon hos den smittede i en tidlig fase av infeksjonen.

I 1995 karakteriserte en forskergruppe ved Statens Serum Institut i København et nytt småmolekylært antigen. Det blir utskilt aktivt under bakteriell vekst og ble kalt ESAT-6 (Early Secretory Antigenic Target 6-kDa). Fra samme genområde hos M tuberculosis, kalt RD1 (region of difference 1), ble det i tillegg karakterisert et lavmolekylært kultur-filtrat-protein, CFP10 , som kodes av et tilstøtende gen. CFP-10 synes å ha de samme egenskaper som ESAT-6, og i arbeidet med å utvikle en diagnostisk test fant man at en kombinasjon av disse to øker sensitiviteten (1). Og det er disse to antigenene som benyttes $i$ de to kommersielt tilgjengelige testene: Quantiferon TB Gold (QFT) og T-SPOT. Prinsippet er å inkubere ESAT-6 og CFP-10 i et sentrifugat av testpersonens leukocytter i 24 timer. Dersom det finnes en populasjon av spesifikke T-celler som er blitt sensitivisert som følge av kontakt med M tuberculosis, vil de frigjøre interferon- $\gamma$ når de på nytt stimuleres av kontakt med de spesifikke antigenene. QFT måler mengden interferon- $\gamma$ som frigjøres, mens T-SPOT måler antall sensitiviserte lymfocytter (fig 1).

\section{Spesifisitet}

Et stort problem med tuberkulintestene har ært den lave spesifisiteten. De kryssreagerer med både BCG og en lang rekke mykobakterielle miljøbakterier, som finnes $i$ jord og vann. I et land med en nesten fullvaksinert befolkning har dette bydd på betydelige problemer ved tolking av testene. Man har måttet operere med begrepet superinfisert, «på toppen av BCG», som defineres som en økning hos vaksinerte personer i tuberkulintestutslaget på minst $10 \mathrm{~mm}$ eller et utslag over $15 \mathrm{~mm}$ dersom resultatet av tidligere tuberkulintest ikke er kjent (2).

I tuberkuloseforskriftene fra 2002 ble det gitt en klar anbefaling om at personer under 35 år som anses som latent infiserte skal tilbys profylaktisk behandling. Etter 35-årsalder øker bivirkningsfrekvensen, slik at anbefalingen er en avveining i hvert tilfelle (2). På grunn av den lave spesifisiteten har man imidlertid i praksis sjelden valgt å starte opp profylaktisk behandling på bakgrunn av at personen er definert som superinfisert ut ifra en tuberkulintest dersom det ikke i anamnesen er tydelige holdepunkter for en aktuell infeksjon. Spesifisitetsproblemet blir veldig tydelig ved miljøundersøkelser i helseinstitusjoner etter ubeskyttet eksponering. Mange har deltatt i flere miljøundersøkelser tidligere, og positivt resultat av ny tuberkulintest skyldes ofte en forsterkningseffekt. Det betyr at tidligere tuberkulintester har stimulert til danning av sensitiviserte T-hukommelsesceller. Når tuberkulin da settes på nytt, øker utslaget og testen blir falskt positiv.

Ikke bare har ESAT-6 og CFP-10 evnen til å fremkalle en sterk spesifikk immunrespons, RD1-regionen i genomet som koder for dem, er nesten unik for $M$ tuberculosis. I en oversiktsartikkel fant man at spesifisiteten på IGRA i de inkluderte studiene var $90-100 \%$, med en overvekt over $95 \%$ (3). I en BCG-vaksinert gruppe på 216 personer i Japan uten kjent tuberkuloseeksponering fant man at $2 \%$ var QFT-positive, mens $65 \%$ av de 113 som hadde tilgjengelig tuberkulintest var tuberkulinpositive (4). Blant 155 eksponerte helsearbeidere ved Akershus, Ullevål og Haukeland universitetssykehus var $2 \%$ smittet ut fra IGRAresultatene, lavere enn man tidligere har antatt. Fra før var 15 definert som superinfiserte ved tuberkulintest, og vi fant også 27 nye superinfiserte. Det vil si at 42 personer ut fra gjeldende retningslinjer skal følges opp med årlige røntgenbilder av thorax og polikliniske kontroller, som impliserer betydelig ressursbruk og ikke minst engstelse og psykisk belastning for den enkelte (5).

\section{Ingen gullstandard}

Likevel finnes det fortsatt ingen gullstandard som definerer om et individ er infisert med tuberkulose. Dette ligger i M tuberculosis' natur, da den i over $95 \%$ av tilfellene ikke forårsaker en direkte aktiv, men latent, infeksjon. Ved en latent infeksjon kan man vanligvis ikke påvise levende tuberkelbasiller og dermed heller ikke si sikkert at personen er infisert. Verken IGRA eller tuberkulintestene skiller mellom aktiv og latent tuberkulose. Så hvilken test er mest pålitelig? Et entydig svar på dette kan ikke gis, men en god pekepinn får man ved å studere hvilke av de to testene som best korrelerer med graden av eksponering. Her er resultatene klare: I en studie av et utbrudd i en engelsk skole korrelerte IGRA godt med antall timer elevene ble eksponert, mens tuberkulinstatus korrelerte først og fremst med BCG-status (6). En lang rekke andre studier har senere bekreftet dette funnet, og internasjonalt er man i ferd med å gå bort fra tuberkulintesting. IGRA innføres i stadig flere sammenhenger, ikke minst i screening av risikogrupper og oppfølging av eksponerte.

\section{Sensitivitet}

Den gruppen det er lettest å definere sensitiviteten for, er de som har aktiv lungetuberkulose og positiv sputumprøve. For denne gruppen varierer tuberkulintestens sensitivitet fra $100 \%$ (7) til $63 \%$ (8). For IGRA rapporterte en metaanalyse en gjennomsnittlig sensitivitet for QFT på 78\% og 90\% for T-SPOT (9). Det er særlig studier som inkluderer immunsupprimerte pasienter, barn og gravide som trekker sensitiviteten ned for QFT, noen studier har rapportert sensitivitet på $70 \%$ og under $(10,11)$. Selv om QFT er enklest og billigst, og derfor er den testen som nå er til- 
gjengelig fra de fleste universitetssykehusene, er den generelle oppfatningen at T-SPOT benyttes for disse gruppene. Denne testen utføres kun ved Folkehelseinstituttet.

\section{Retningslinjene bør revurderes}

Etter at en nasjonal komité hadde gitt sine anbefalinger vedtok Helse- og omsorgsdepartementet nye retningslinjer for screening av risikogrupper for tuberkulose (12). Den lenge varslede omleggingen fra å screene hele årskull av ungdommer med tuberkulintest til å rette innsatsen mot bestemte risikogrupper, som eksponert helsepersonell (miljøundersøkelser), asylsøkere ved ankomst og innvandrere fra høyendemiske land og deres barn, er fornuftig. I de nye forskriftene heter det at immunologisk blodtest (IGRA) innføres som en del av undersøkelsen for grupper som utredes for latent infeksjon. Det blir anbefalt at «blodtesten skal benyttes som en bekreftende test hos personer med positiv tuberkulinreaksjon». Den anbefalte fremgangsmåten er at man først skal utføre tuberkulintest. Dersom den er positiv, utføres blodtesten $(12,13)$.

I den senere tid har det kommet flere studier som gjør at jeg mener man må vurdere å endre anbefalingen. Siden smitteoverføring av tuberkulose til helsepersonell i Norge synes å være ganske lav, kan den anbefalte totrinnsscreeningen (tuberkulintest etterfulgt av IGRA) i utgangspunktet høres fornuftig ut, selv om tuberkulintestene har en lav spesifisitet. Det viktigste argumentet mot en slik praksis er at enkelte nyere studier ikke bare viser at tuberkulintestene har en uakseptabelt lav spesifisitet. I en tysk studie fant man at $40 \%$ av helsearbeidere med latent infeksjon definert av positivt funn ved IGRA hadde en negativ tuberkulintest (14). Disse ville ha vært falskt negative hvis man kun utførte QFT ved positiv tuberkulintest. Det er også mye som tyder på at en positiv IGRA-test korrelerer bedre til sannsynligheten for å få en reaktivering av latent tuberkulose hos den enkelte pasient (15).

\section{Konklusjon}

Når testene samsvarer så dårlig, blir man nødt til å velge hvilken test man skal stole på. Ut fra den nå etter hvert betydelige mengden forskning som demonstrerer IGRAs overlegenhet, kan jeg ikke forstå annet enn at man bør gå helt bort fra tuberkulintester. Hvis man holder fast på komiteens anbefalinger om at alle med mistenkt infeksjon først skal testes med tuberkulintest og at kun de positive skal testes med IGRA, risikerer man å miste et betydelig antall som burde ha vært behandlet. I Nienhaus' studie ville man mistet $40 \%$ (14) .

Jeg tror ikke man sparer ressurser ved å beholde tuberkulintestene, snarere tvert imot. Å sette tuberkulintester krever erfaring, og det brukes betydelige ressurser til å lære opp personell. Dessuten må den som testes komme tilbake og få lest av resultatet,

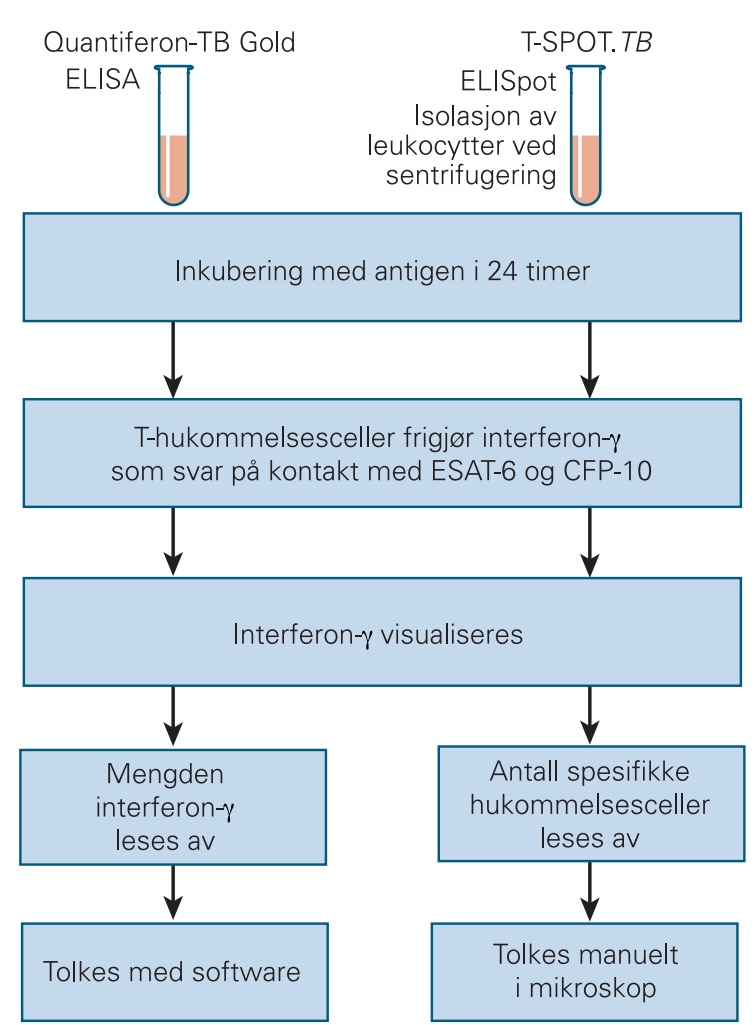

Figur 1 Prinsipper for de to Interferon-gamma Release Assays (IGRA) som er tilgjengelig i Norge. ELISA = Enzyme-linked immunosorbent assay. ELISpot $=$ Enzyme-linked immunosorbent spot . ESAT-6 = Early Secretory Antigenic Target 6. CFP-10 = Culture Filtrate Protein 10

slik at det blir to konsultasjoner. Med dagens høye lønnsnivå tror jeg dette blir dyrere enn å utføre en IGRA, som i ulike kalkyler har kommet ut med en kostnad på 250-400 kroner (QFT).

Det finnes med andre ord sterke faglige argumenter for å gå bort fra tuberkulintester og ingen økonomiske argumenter mot. Ved Lovisenberg Diakonale Sykehus har vi i lang tid testet alle med QFT, og vi benytter ikke lenger tuberkulintester. Helse- og omsorgsdepartementet bør komme på banen, gå igjennom den forskning og erfaring som foreligger, og utforme nye retningslinjer.

Oppgitte interessekonflikter: Ingen

\section{Litteratur}

1. van Pinxteren LA, Ravn P, Agger EM et al. Diagnosis of tuberculosis based on the two specific antigens ESAT-6 and CFP10. Clin Diagn Lab Immunol 2000; 7: 155-60.

2. Smittevern 7: Forebygging og kontroll av tuberkulose. En veileder. Oslo: Nasjonalt folkehelseinstitutt, 2002

3. Pai M, Kalantri S, Dheda K. New tools and emerging technologies for the diagnosis of tuberculosis: part II. Active tuberculosis and drug resistance. Expert Rev Mol Diagn 2006; 6: 423-32.

4. Mori T, Sakatani M, Yamagishi F et al. Specific detection of tuberculosis infection: an interferongamma-based assay using new antigens. Am J Respir Crit Care Med 2004; 170: 59-64.

5. Storla DG, Kristiansen I, Oftung F et al. Use of interferon gamma-based assay to diagnose tuberculosis infection in health care workers after short term exposure. BMC Infect Dis 2009; 9: 60.

6. Ewer K, Deeks J, Alvarez L et al. Comparison of T-cell-based assay with tuberculin skin test for diagnosis of Mycobacterium tuberculosis infection in a school tuberculosis outbreak. Lancet 2003; 361: 1168-73.

7. McConkey SJ, Youssef FG, Azem E et al. Evaluation of a rapid-format antibody test and the tuberculin skin test for diagnosis of tuberculosis in two contrasting endemic settings. Int J Tuberc Lung Dis 2002 6: $246-52$

8. Liebeschuetz S, Bamber S, Ewer K et al. Diagnosis of tuberculosis in South African children with a T-cell-based assay: a prospective cohort study. Lancet 2004; 364: 2196-203.

9. Pai M, Zwerling A, Menzies D. Systematic review: T-cell-based assays for the diagnosis of latent tuberculosis infection: an update. Ann Intern Med 2008; 149: 177-84.

10. Syed Ahamed Kabeer B, Sikhamani R, Swaminathan $\mathrm{S}$ et al. Role of Interferon gamma Release Assay in active TB diagnosis among HIV infected individuals. PLoS One 2009; 54: e5718.

11. Pai M. Alternatives to the tuberculin skin test: Interferon-gamma Assays in the diagnosis of mycobacterium tuberculosis infection. Indian J Med Microbiol 2005; 23: $151-8$

12. Anbefalinger for bruk av Interferon-gamma Release Assays (IGRA) ved diagnostikk av tuberkulose i Norge. Oslo: Folkehelseinstituttet, 2009.

13. Helse- og omsorgsdepartementet. Tema. Folkehelse. Kommentarer til faglige anbefalinger om innholdet i tuberkuloseundersøkelse. www. regjeringen.no/nb/dep/hod/tema/folkehelse/ kommentarer-til-faglige-anbefalinger-om-.html? id $=531534$ (5.10.2009).

14. Nienhaus A, Schablon A, Bacle CL et al. Evaluation of the Interferon-gamma Release Assay in healthcare workers. Int Arch Occup Environ Health 2008 ; 81: $295-300$

15. Diel R, Loddenkemper R, Meywald-Walter K et al. Predictive value of a whole blood IFN-gamma assay for the development of active tuberculosis disease after recent infection with Mycobacterium tuberculosis. Am J Respir Crit Care Med 2008; 177: 1164-70.

Manuskriptet ble mottatt 17.8. 2009 og godkjent

5.11. 2009. Medisinsk redaktør Siri Lunde. 